\title{
The effect of copper on the content and composition of saccharides in oat plants
}

\author{
MARIA SLUSARCZYK ${ }^{1}$ and MARIA RUSZKOWSKA 2 \\ ${ }^{1}$ Department of Biochemistry and Physiology of Crop Plants, \\ Institute of Cultivation, Fertilization and Soil Science, \\ Osada Pałacowa, 24-100 Puławy, Poland \\ 2 Laboratory of Plant Nutrition, Institute of Cultivation, \\ Fertilization and Soil Science, Osada Pałacowa, 24-100 Puławy, Poland
}

(Received: November 27, 1984)

\begin{abstract}
The relationship between the content and composition of saccharides and the dose and time of application of copper sulphate was studied in different organs and stages of development of oats (Avena sativa L. var. 'Udycz żółty'). The plant material was obtained from pot experiments run on low peat, deficient in copper. Under these conditions, oat plants contained less soluble sugars, hemicelluloses and cellulose than plants receiving a sufficient amount of this element. The differences in the composition of the individual saccharide fractions depended on the dose of copper and time of its application, as well as on the organ and stage of development of the oat plant. In grain of oats grown in copper deficient peat, increased amounts of pentoses (arabinose and xylose) were found concomitantly with a lowered glucose content. Attempts to explain the changes in the sugar metabolism under conditions of copper deficiency and the role of this micronutrient in seed formation are presented.
\end{abstract}

\section{INTRODUCTION}

Copper has been known for a long time to be an indispensable micronutrient to cereal yields. The machanism by which it affects the growth and development of these plants has not, however, yet been adequately explained.

Studies done at the Laboratory of Plant Nutrition of IUNG (Institute of Cultivation, Fertilization and Soil Science) in Pulawy have shown that copper has a favorable influence on the yield and structure of oats (Wojcieska, 1982a, b; R u s z k ow ska et al., 1983). In copper deficient plants, disorders in photosynthesis ( 
B a szyński et al., 1978; Wojcieska, 1983a), in ascorbic acid oxidase activity ( $\mathrm{R} \mathrm{uszkowska}$ and Łyszcz, 1975; Łyszcz et al., 1976; Eyszcz, 1982), in respiration ( $\mathrm{Zinkiewicz}$ and $\mathrm{Slusar-}$ c z y k, 1981; Z inkiewicz et al., 1985), in mineral metabolism and other metabolism processes ( $\mathrm{R} \mathrm{u} \mathrm{szkowska,1983;} \mathrm{R} \mathrm{u} \mathrm{s} \mathrm{zkow} \mathrm{ska} \mathrm{et}$ al., 1983; Wo j cieska, 1983b) were stated. Oats, growing under conditions of acute copper deficiency, formed few panicles with mainly infertile spikelets ( y s z c z, 1982 ; W o j cieska, $1982 a ; R$ u s k ows k a et al., 1983).

From the studies by Graham $(1975,1976)$ it can be concluded that the reason of poor grain feeling of wheat was the pollen sterility. In oats, W e ryszko et al. (1982) observed signs of degeneration in pollen and in pistil stigmas under conditions of copper deficiency. Another symptom of copper deficiency in cereals was also excessive tillering of plants (Eyszcz et al., 1976; N a mbiar, 1976; Wojc i e ska, 1982a, b). This leads to the supposition that the lateral shoots, under these conditions, compete with the main shoot for soluble sugars, what also can be the reason for impaired development and filling of grain.

Because the level and composition of saccharides are important indicators of the physiological state of plants (S l u s a r z y k, 1980a), studies were undertaken to determine the changes in the content and composition of saccharides in oat plants growing under conditions of copper deficiency, in comparison with plants well supplied with this element.

\section{MATERIAL AND METHOD}

The experiments were done in a greenhouse on oats (Avena sative L. var. 'Udycz Żólty') grown in Mitscherlich pots on low, moss-carex peat containing only $0.5 \mathrm{ppm} \mathrm{Cu}$ (determined in a Westerhoff extract). The pots contained $0.8 \mathrm{~kg}$ (dry mass) of peat $(3.3 \mathrm{~kg}$ of moist peat). In the experiments, different doses or dates of application of copper sulfate (applied to the surface of the soil) were used according to the following scheme:

I. In 1977 and 1978, the plants were grown from the beginning of vegetation in the presence of three different levels of copper: $O$ (acute deficiency), $5 \mathrm{mg} \mathrm{Cu}$ (moderate deficiency) and $125 \mathrm{mg} \mathrm{Cu}$ per pot, found in earlier experiments to be the optimal dose (R u szk ow s a and Łyszcz, 1975; Łyszcz, 1982). The plants were harvested at: 1) tillering stage, 2) earing, 3) full maturity.

II. In 1979 and $1980,125 \mathrm{mg} \mathrm{Cu}$ per pot were applied in different stages of plant development: after emergence, during tillering, at 
shooting, just before coming into ear or at the beginning of blooming. Plants which had not received copper during their entire vegetation served as controls. The plants were harvested three times starting from the grain filling phase to milk ripeness, in 6-7 day intervals.

The remaining nutrients in all of the experiments were applied in optimum concentrations. The plants were watered with demineralized water to $60 \%$ water capacity of the peat. Other details of these experiments have been published in previous papers (Wojcieska, $1982 \mathrm{a}, \mathrm{b} ; \mathrm{R}$ us z k ow sk a, 1983).

After harvest, the plants were dried at a temperature of $70^{\circ} \mathrm{C}$, weighed and pulverized. Sugar fractions (fraction a - total soluble sugars, fraction b - hemicelluloses, fraction c - cellulose) were assayed using the Waksman-Stevens method as developed by $\hat{S} \mathbf{l u s a r c z k}$ (1976). Reducing sugars were assayed in the successive steps of analysis by the method of $\mathrm{Dub}$ o is et al. (1956). The presented results are the averages of two repetitions. The composition of the sugar fractions was determined by paper chromatography in a solvent system according to Gaill a r d (1953) (benzene - butanol - pyridine - water, $1: 5: 3: 3$ ) and detected according to Trevelyan et al. (1950) using an ammoniac silver nitrate solution. The results were subjected to analysis of variance and lowest significant differences (LSD) at $P=0.05$ are presented on the figures.

\section{RESULTS}

The effect of copper supply

In whole plant shoots in the shooting stage, only small differences under the influence of increasing copper doses were found in pattern of the saccharide fractions (Fig. 1).

During and after the stage of ear development a significant increase of the saccharide content of the studied fractions was found in all or-

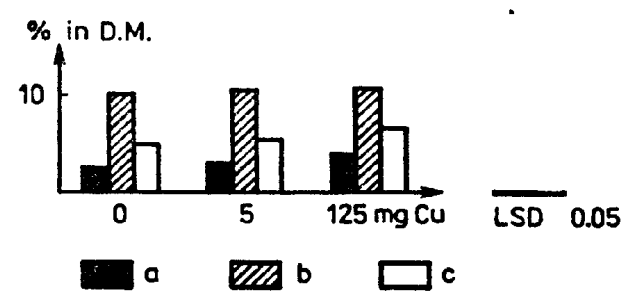

Fig. 1. The effect of copper on the percentage of: a - soluble sugars, b - hemicelluloses, c - cellulose, in the oat plants at the shooting stage (1977-1978) 

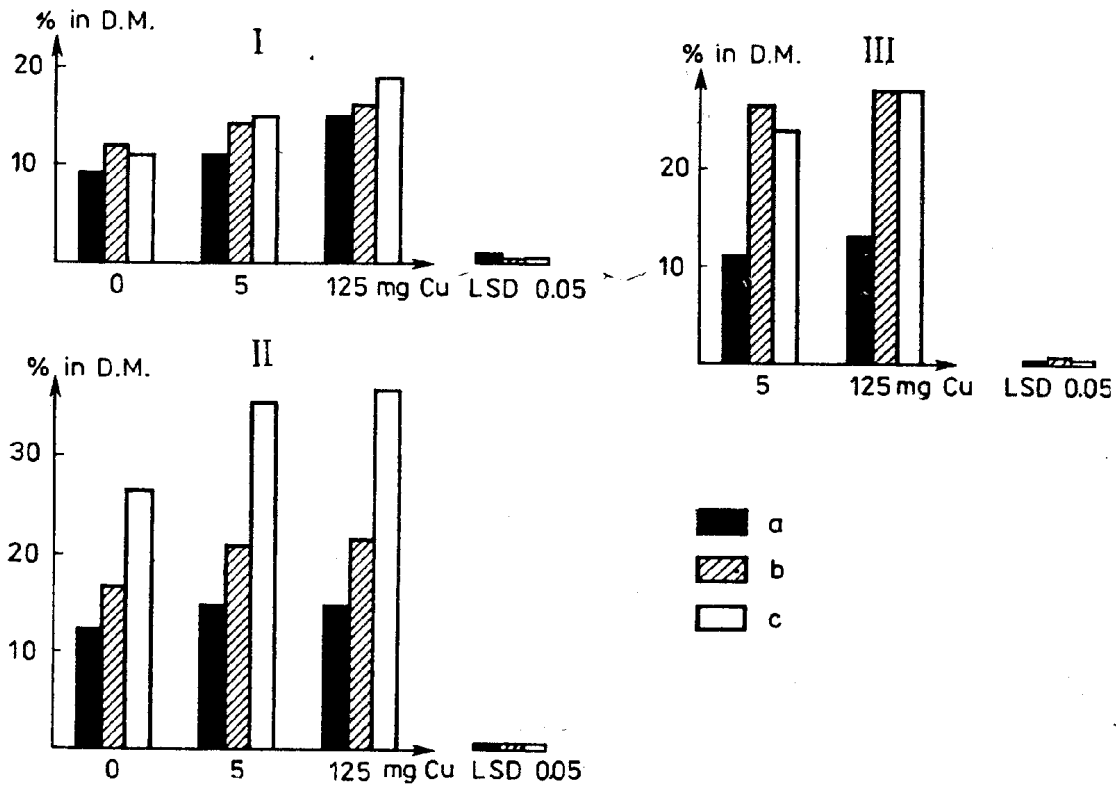

Fig. 2. The effect of copper on the percentage of: a - soluble sugars, b - hemicelluloses, c - cellulose, of: I - leaf blades, II - culms, III - panicles of oat plants just after coming into ear (1977)

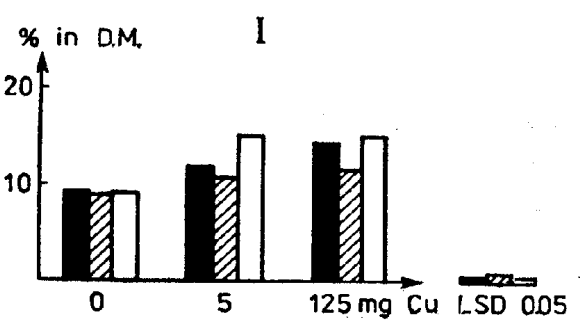

$\%$ in D.M. III

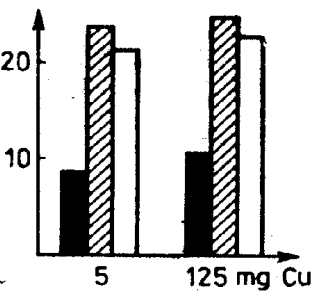

$\overline{\text { LD } 005}$

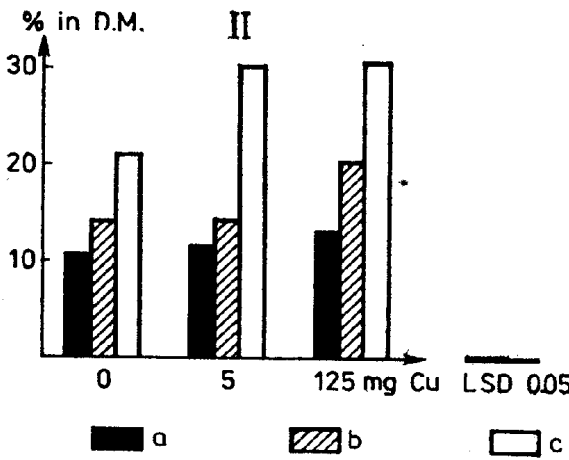

IV

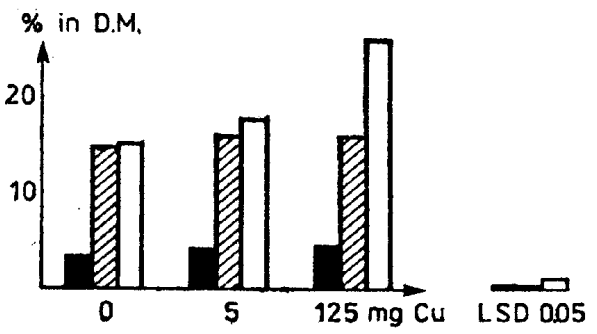

Fig. 3. The effect of copper on the percentage of: a - soluble sugars, b - hemicelluloses, c - cellulose, of: I - leaf blades, II - culms, III - panicles, IV - roots of oat plants at the earing stage (1978) 
gans in both years as a result of copper supplement (Figs. 2, 3 and 4). The greatest differences, reaching $50 \%$, were found in the content of soluble sugars in leaf blades; in the remaining organs these differences amounted up to $20 \%$. The increase in the amount of cellulose under the influence of copper was about $50 \%$ in leaf blades, culms and roots.

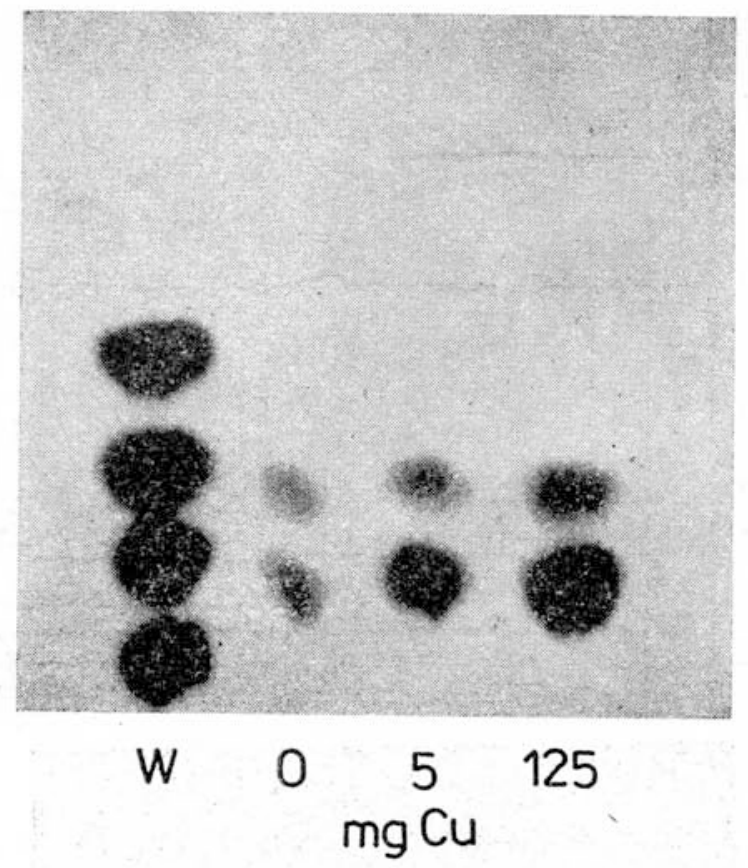

Fig. 4. The effect of copper on the soluble sugars in the leaf blades of oats at the earing stage: $\mathrm{W}$ - standard, starting from the bottom: galactose, glucose, fructose, xylose

Similar results, were obtained in the full ripeness phase. Copper deficient plants contained the lowest amounts of soluble sugars, hemicelluloses and cellulose (Fig. 5). The sugar content of grain deserves special attention (Fig. 6 and 7). The grain was rarely developed on the deficient plants. These grain, did not contain glucose at all. It was found in the grain of plants receiving copper. The amount of glucose in plants given $125 \mathrm{mg} \mathrm{Cu}$ was many times higher than that in plants given $5 \mathrm{mg} \mathrm{Cu}$ (Fig. 6). The grain of the studied plants differed also in the sugar content of the hemicelluloses. Plants not fertilized with copper contained mainly arabinose and xylose and a small amount of galacturonic acid and very little glucose. Plants treated with $5 \mathrm{mg} \mathrm{Cu}$ contained galacturonic acid, very little glucose, arabinose and xylose. Those 

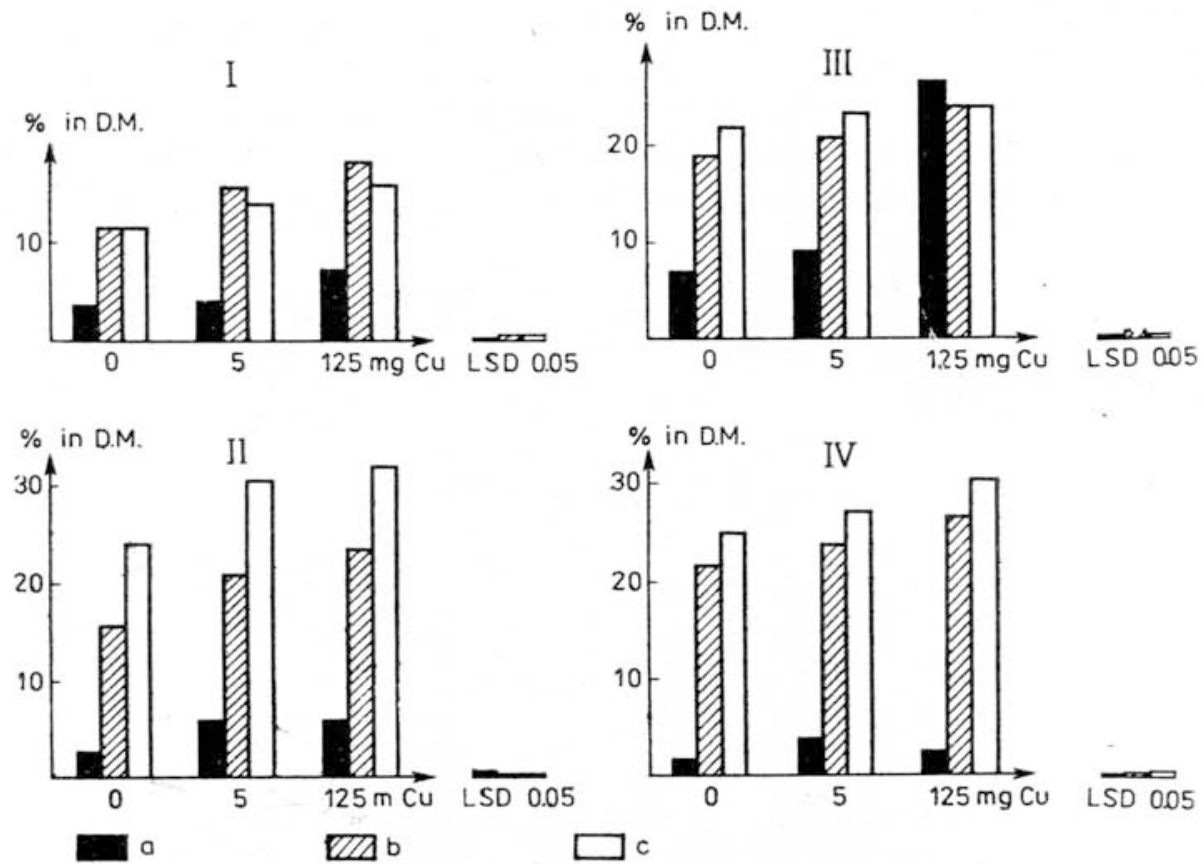

Fig. 5. The effect of copper on the percentage, of: a - soluble sugars, b - hemicelluloses, c - cellulose, of: I - leaf blades, II - culms, III - grain, IV - roots of oats at the full ripeness stage (1978)

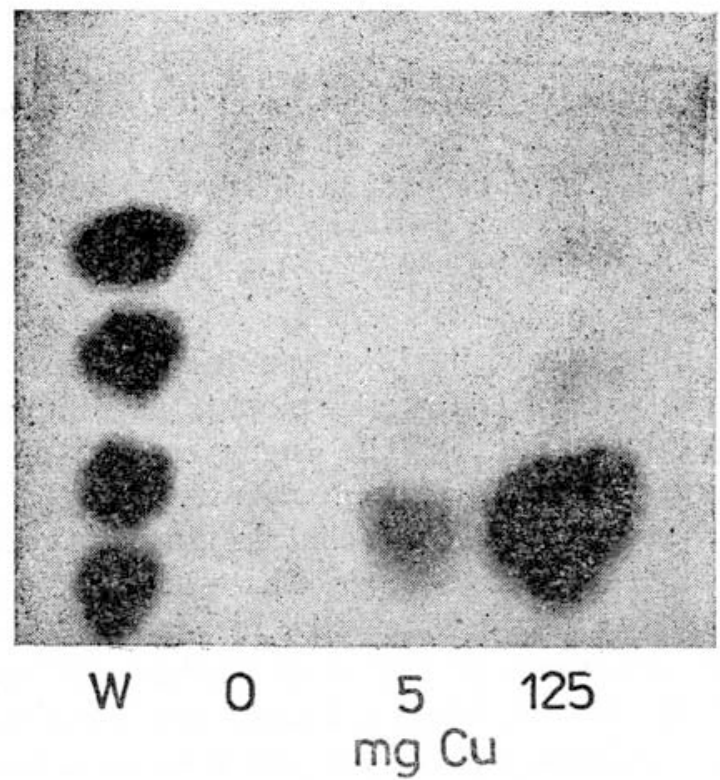

Fig. 6. The effect of copper on the soluble sugars in oat grains. W - standard, starting from the bottom: galactose, glucose, fructose, xylose 


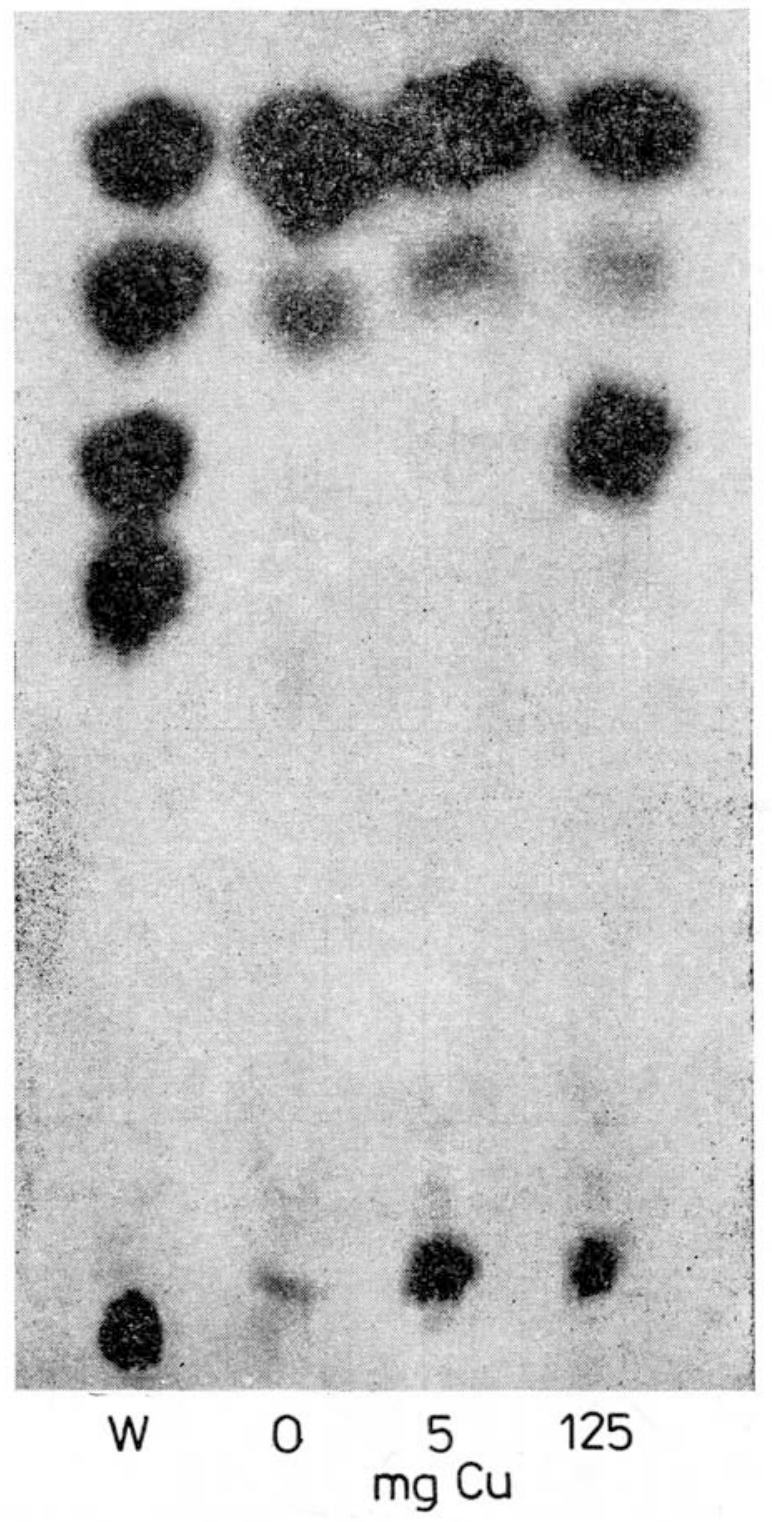

Fig. 7. The effect of copper on the sugar composition after the hydrolysis of hemicelluloses from oat grains. W - standard, starting from the bottom: galacturonic acid, galactose, glucose, arabinose, xylose

plants given $125 \mathrm{mg} \mathrm{Cu}$ contained galacturonic acid, large quantities of glucose but less arabinose and xylose (Fig. 7). It should be noted that at $5 \mathrm{mg} \mathrm{Cu}$, the amount of arabinose was already lower than in the control. 
The effect of time of copper application

In the main shoots of copper treated plants at the dose of $125 \mathrm{mg}$ $\mathrm{Cu}$ per pot after plant emergence an increase of soluble sugar content was observed (from a few to $50 \%$ ) in comparison to control plants (Fig. 8). The use of an identical dose of copper at tillering and shooting stages also caused a significant increase in the soluble sugar content which was especially evident in the plants harvested during the grain filling. Only
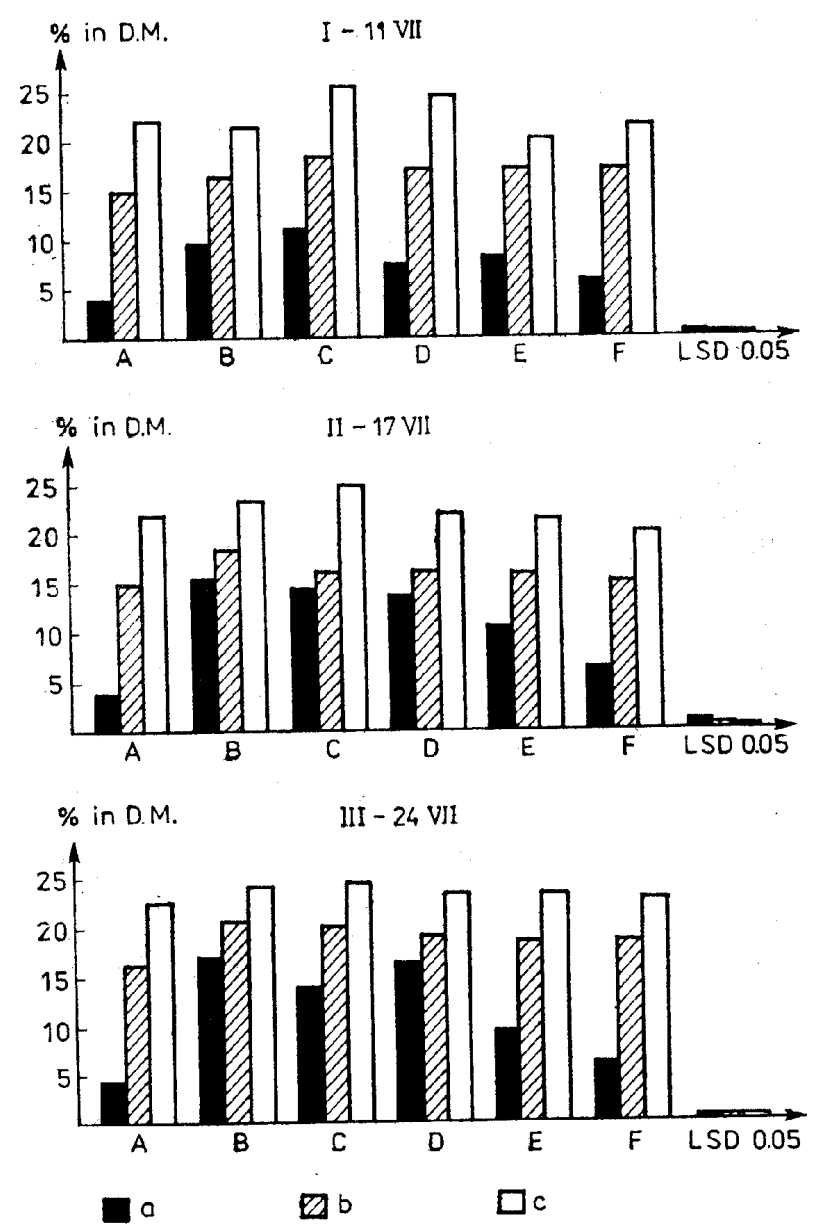

Fig. 8. The effect of copper applied at different growth stages of oats on the contents of: a - soluble sugars, b - hemicelluloses, c - cellulose in the main shoots. I - early stage of filling grain, II - a later stage of filling grain, III milk ripeness stage. A - $0 \mathrm{mg} \mathrm{Cu}$ (control), B - $125 \mathrm{mg} \mathrm{Cu}$ after emergence, $\mathrm{C}-125 \mathrm{mg} \mathrm{Cu}$ during tillering, $\mathrm{D}-125 \mathrm{mg} \mathrm{Cu}$ during shooting, $\mathrm{E}-125 \mathrm{mg}$ $\mathrm{Cu}$ just before coming into ear, $\mathrm{F}-125 \mathrm{mg} \mathrm{Cu}$ during blooming 
copper given during blooming did not cause any changes in the content of soluble sugars in the main shoots of plants.

The effect of copper on the soluble sugar content was greater in the lateral shoots. The dose of $125 \mathrm{mg}$ per pot applied to plants after emergence and at tillering stages caused a 3-4 fold increase in this sugar fraction in comparison with the control plants (Fig. 9). However, the later the stage the lower the effect of copper was observed. It was no effect of copper at blooming stage.

Similar, although less pronounced, changes were found in the hemicellulose and cellulose fractions both in the main and lateral shoots as
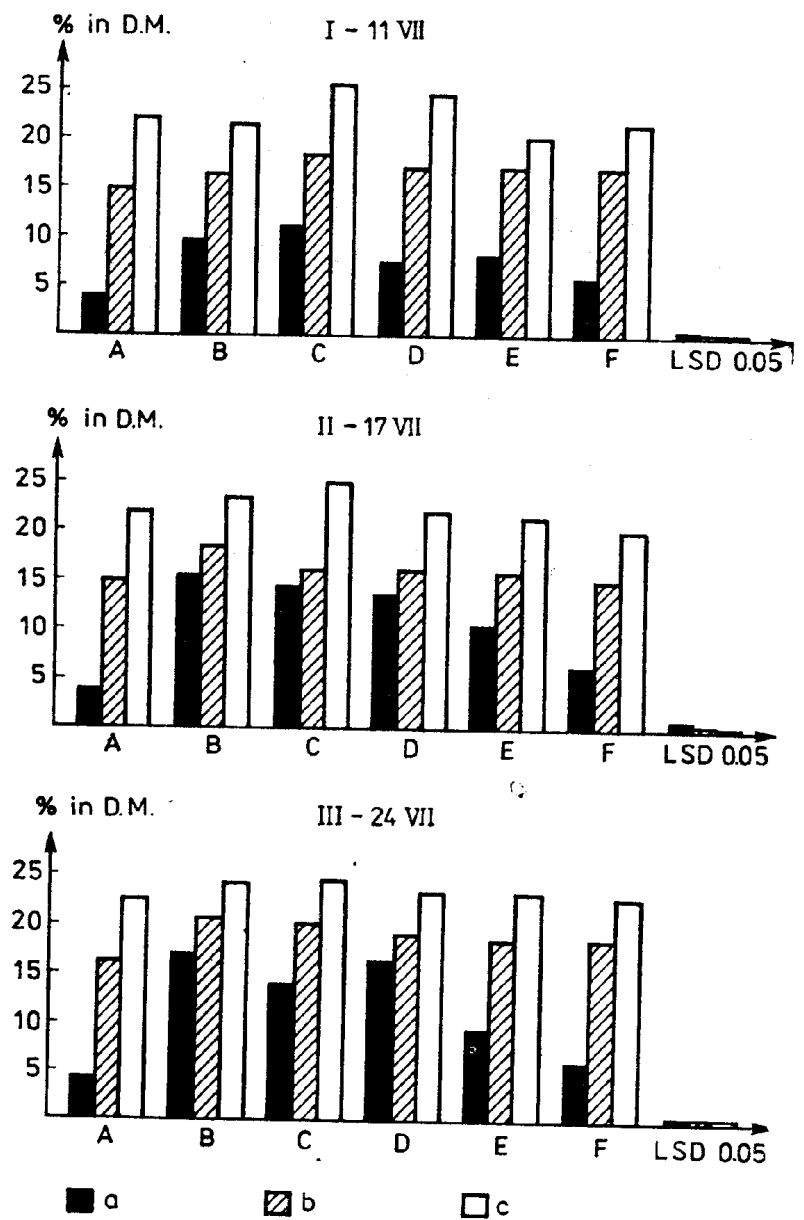

Fig. 9. The effect of copper applied during different stages of oat development on the content of: a - soluble sugars, b - hemicelluloses, c - - cellulose in lateral shoots. Remaining symbols as in Fig. 8 
the result of copper supplement at different stages of development (Figs. 8 and 9).

Chromatographic analysis of the soluble sugars in the main shoots of oats in the milk ripeness stage showed significantly lower amounts of glucose and fructose in copper deficient plants (Fig. 10) than in those receiving sufficient amounts of this element from the start of vegetation. Also in lateral shoots of copper deficient plants a very low level of soluble sugars was found (Fig. 11). Chromatographic analysis of sug-
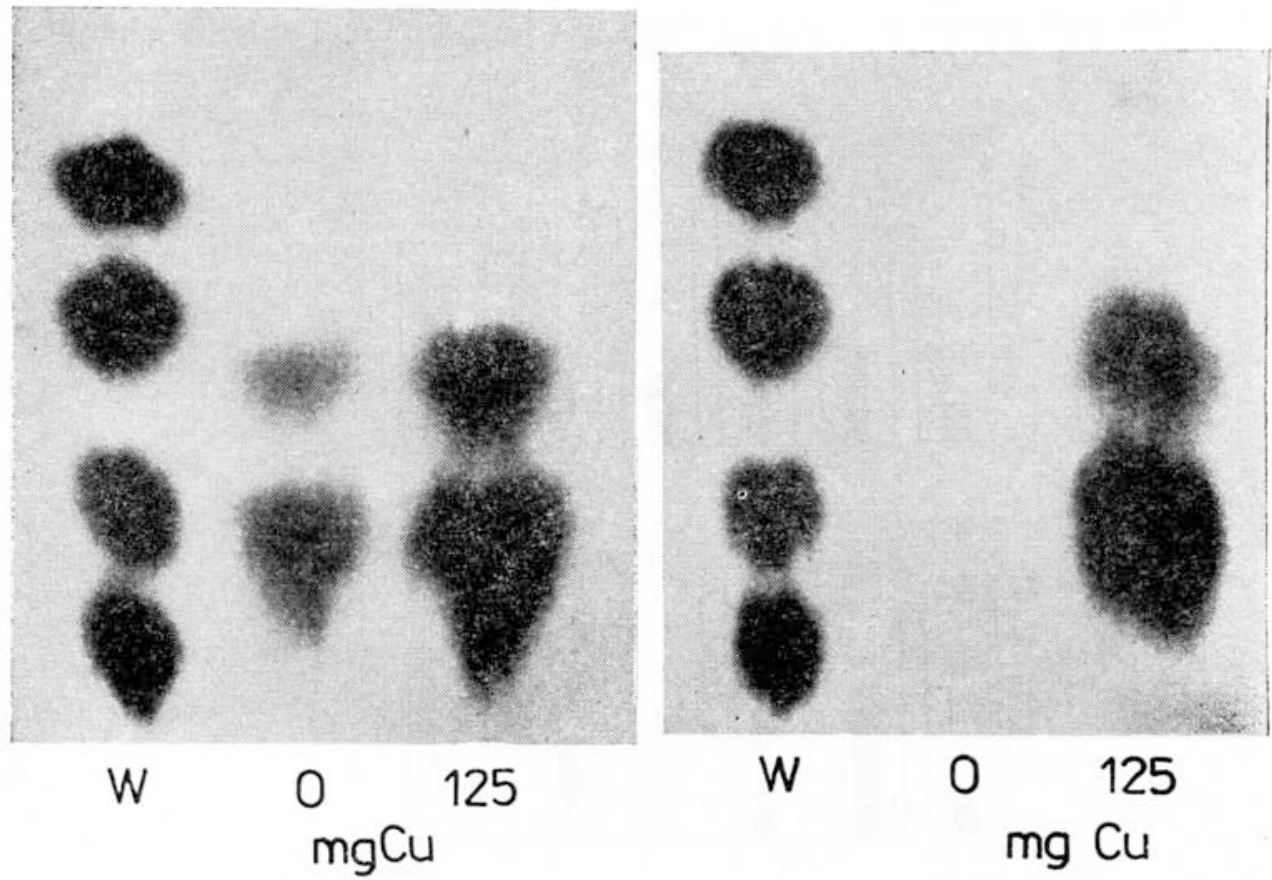

Fig. 10. The effect of copper on the soluble sugars in the main shoots of oats at milk ripeness stage. W - standard, starting from the bottom: galactose, glucose, fructose, xylose

Fig. 11. The effect of copper on the soluble sugars in the lateral shoots of oats at milk ripeness stage. W - standard, starting from the bottom: galactose, glucose, arabinose, xylose

ars after hydrolysis of hemicelluloses during milk ripeness stage both in the main and lateral shoots showed a similar pattern of sugars as a recation to copper. Plants not supplied with copper contained only traces of glucose in this saccharide fraction (Fig. 12), whereas a sufficient supply of copper caused a cretain increase in the glucose content of the hemicellulose fraction. 


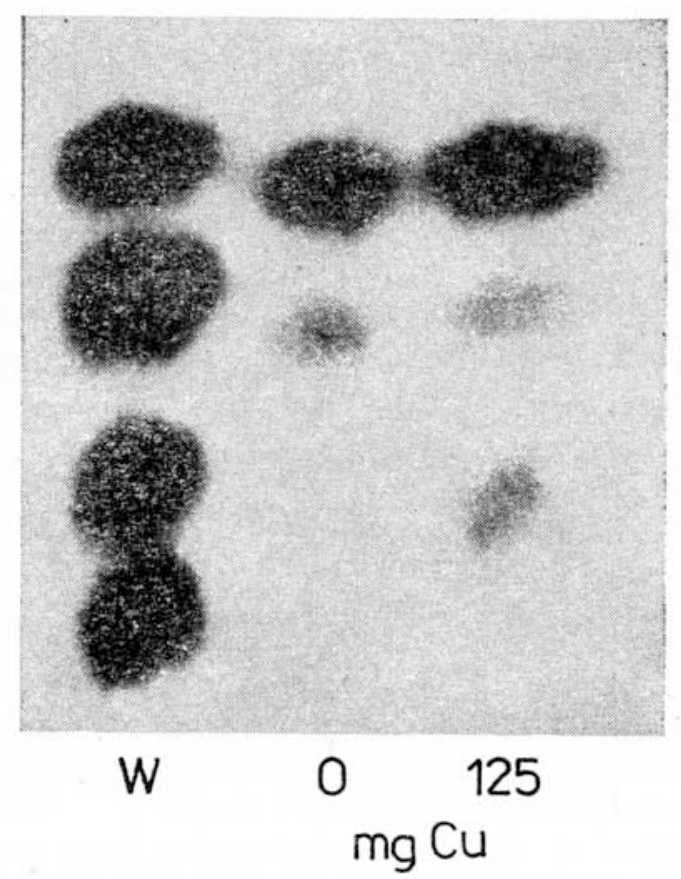

Fig. 12. The effect of copper on the sugar composition after the hydrolysis of hemicelluloses in main shoots of oats at milk ripeness stage. W - standard, starting from the bottom: galactose, glucose, arabinose, xylose

Changes in the occurrence of soluble sugars in the lateral shoots fell in a very characteristic pattern for the time of application (Fig. 13). Differences in time of application of optimal copper doses caused mainly changes in the occurrence of glucose and fructose. The greatest amounts of these sugars were found in plants received copper after emergence smaller amounts when copper was given at tillering and at shooting stages. Chromatographic analysis of sugars after hydrolysis of hemicelluloses from the lateral shoots showed (Fig. 14) that the highest glucose content was found in plants received copper at tillering. Applying copper during the later stages did not cause any increase in the amounts of both sugar fractions of in plants.

\section{DISCUSSION}

The lowered saccharide content, especially that of soluble sugars in oat plants grown under conditions of copper deficiency, found in this study and in earlier reports ( $\mathrm{S}$ l u sarczyk, $1980 \mathrm{~b}$; R u szkow ska et al., 1983) could have been caused by reduced intensity and activity 


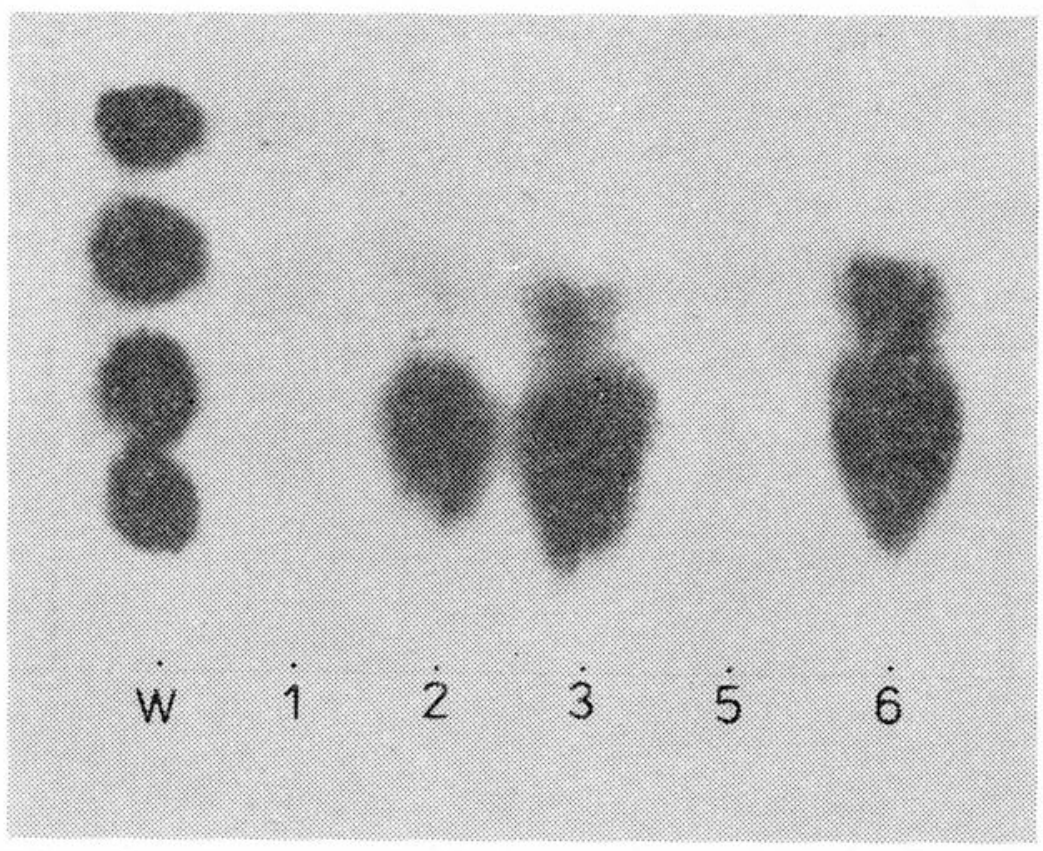

Fig. 13. The effect of copper applied during different stages of oat development on the soluble sugars in lateral shoots. W - standard, starting from the bottom: galactose, glucose, fructose, xylose. $1-0 \mathrm{mg} \mathrm{Cu}$ (control), $2-125 \mathrm{mg} \mathrm{Cu}$ after emergence, $3-125 \mathrm{mg} \mathrm{Cu}$ at tilering stage, $5-125 \mathrm{mg} \mathrm{Cu}$ at earing stage, $6-125 \mathrm{mg} \mathrm{Cu}$ at blooming stage

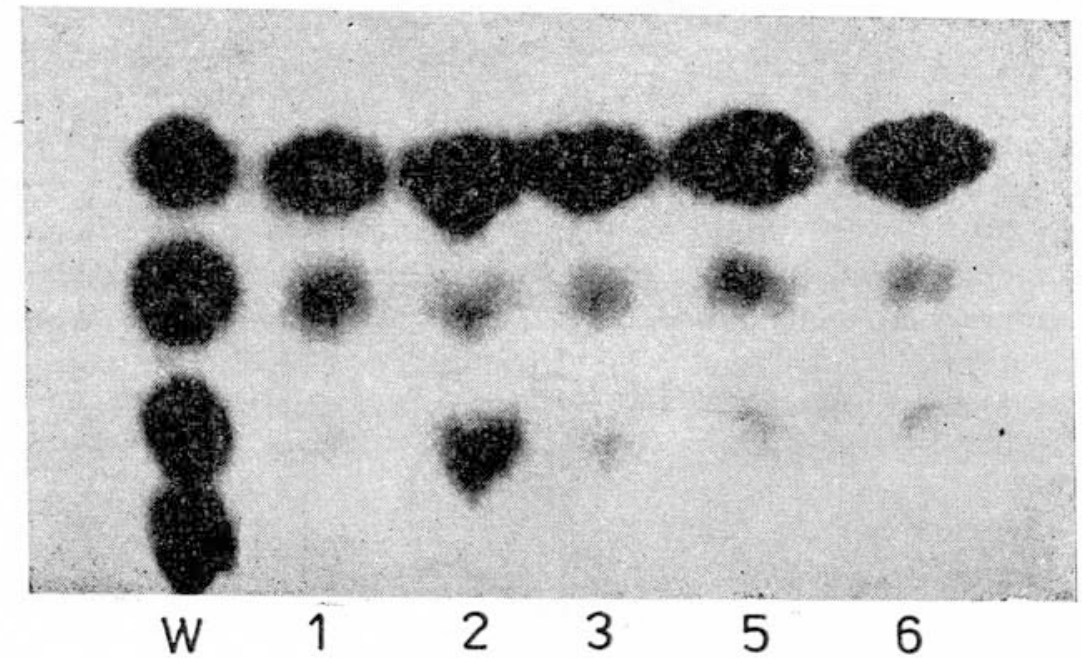

Fig. 14. The effect of copper applied during different stages of oat development on the sugars after hydrolysis of hemicelluloses from lateral shoots. W - standard, starting from the bottom: galactose, glucose, arabinose, xylose. Remaining symbols as in Fig. 13 
of photosynthesis ( $\mathrm{Eyszcz}$ et al., 1976; B a szyński et al., 1978; W o j c i e s ka, 1983a), as well as by an increase in the intensity of dark respiration of the main shoots from the earing stage and lateral shoots during the entire vegetation period ( $\mathrm{Z}$ inki e w i c $\mathrm{z}$ et al., 1980; $\mathrm{Z}$ inkiewicz and SIusarczyk, 1981; Zinkiewicz et al., 1985). The contents of all of the studied saccharide fractions (soluble sugars, hemicelluloses, cellulose) increased under the influence of copper, from the early growth stages to the late stages of grain filling. These results do not entirely agree with those of $\mathrm{Grah}$ a m (1980), who in similax experiments with wheat found an increase in the content of soluble sugars as the result of copper supply, only up to anthesis.

In the studies of Zinkiewicz and Slusarczyk (1981) and Slusarczyk and Zinkiewicz (1983), an interdependency was observed between the intensity of dark respiration of oat plants differentially supplied with copper and their soluble sugar contents, especially that of glucose. In these studies, the sugar contents were assayed in the same shoots used for measuring respiration. The higher the respiration rate of the shoots, the lower glucose content was found under the conditions of copper deficiency. The higher respiration rate of lateral shoots in comparison with main shoots coincided with greater losses of glucose in lateral shoots of copper deficient plants. Applying copper during tillering or shooting to plants grown from the begining of vegetation under copper deficiency caused a decrease in respiration, which was also reflected in an increase of the glucose content.

According to the opinion of Wojcieska $(1983 \mathrm{a}, \mathrm{b})$, the decrease in the size of the pool of photosynthetic products resulting from the decrease in photosynthetic intensity and the increase of the respiration intensity of plants growing under conditions of copper deficiency, are not great enough to directly inhibit the development of the panicle and grain. More likely, hormonal disorders come into play here. In light of the presented results, the increase in the amount of pentoses in oat grains grown under conditions of severe copper deficiency and the concomitant significant decrease in the glucose content seem to indicate changes in glucose transformation (Ślus a r c y k, 1980a; Z inkiewicz and Slusarczyk, 1981; Slusarczyk and Zinkiewicz, 1983). Under such conditions, the degradation of glucose in the process of respiration could be carried out to a greater degree in the pentose phosphate pathway, which is also suggested in the case of other physiological stresses (S lusarczyk, 1978; Slusarczyk, 1980a; Slusarczyk et al., 1985). The discussed changes in the metabolism of saccharides under conditions of copper deficiency are most probably connected with disorders of the balance between the systems of growth 
stimulators - growth inhibitors - ATP level, which can be the direct cause of the inhibition of panicle and grain development in oats. As has been shown by P is k o r n ik ct al. (1981), a lack of ATP caused sterility of pollen in hazel shrubs. The question, therefore, should be examined if the cereal pollen sterility found by $\mathrm{Graham}(1975 ; 1976)$ to be caused by copper deficiency is not also caused by a lowered ATP level, and if this in turn, is not the result of disorders of the saccharide metabolism.

Independent of the presented suggestions, this study's finding of the reduced hemicellulose content is in agreement with the study of $R$ a h i mi and Bussler (1973) and the decrease of cellulose and lignin (R us zk ow ska et al., 1983) in oat plants suffering from copper deficiency, is proof that this deficit caused weakness of the cell wall structure, which in turn, becomes the cause of the culm underdevelopment often observed under such conditions (Wojcieska, $1982 \mathrm{a}, \mathrm{b}$ ). Weak culm and ear development may be one of the reasons for poor seed formation in cereals growing under conditions of copper deficiency in the soil.

\section{CONCLUSIONS}

1. Copper deficient oat plants contain less soluble sugars, hemicelluloses and cellulose in comparison with plants sufficiently supplied with this element. Differences in the content of the saccharide fractions depend on the dose of copper and the time of its application, as well as, on the organ and phase of development of the oat plant.

2 . In the grain of oats grown under conditions of copper deficiency, greater amounts of pentoses (xylose and arabinose) are found concomitantly with smaller amounts of glucose. This may indicate a changed pathway of glucose transformation during respiration under conditions of copper deficiency.

\section{REFERENCES}

Baszyński T., Ruszkowska M., Król M. Tukendorf A., Wolińska D., 1978. The effect of copper deficiency on the photosynthetic apparatus of higher plants. Z. Pflanzenphysiol. 89: 207-216.

Dubois M., Gilles K. A., Hamilton J. K., Rebers P. A., Smith F., 1956. Colorimetric method for determination of sugars and related substances. Anal. Chem. 28, 3: 350-356.

G a i 11 ard D. E., 1953. Use of unneutralized hydrolizates in paper chromatography of sugar. Nature 171, 4365: 1160.

Graham R. D., 1975. Male sterility in wheat plants deficient in copper. Nature 254, 5500: 514-515. 
Grah a m R. D., 1976. Physiological aspects of time of applications of copper to wheat plants. J. Exp. Bot. 27: 717-724.

Graham R. D., 1980. The distribution of copper and soluble carbohydrates in wheat plants grown at high and low levels of copper supply. Z. Pflanzenernähr. u. Bodenkunde 143: 161-169.

Ły s z c z S., 1982. Wpływ miedzi na zawartość oksydoreduktaz miedzioproteidowych w roślinach. Pam. pul. 78: 77-96.

Łyszcz S., Ruszkowska M., Wojcieska U., Zinkiewicz E., 1976. The activity of ascorbic acid and catechol oxidase, the rate of photosynthesis and respiration as related to plant organs, stage of development and copper supply. Acta Agrobot. 29: 99-105.

$\mathrm{Nambiar}$ E. K. S., 1976. Genetic differences in the copper nutrition of cereals. I. Differential responses of genotypes to copper. Austral. J. Agric. Res. 27: $453-463$.

Piskornik Z., R ożek S., R a dwa n-K áznica M., 1981. Relation between the ATP content and the viability of filbert pollen (Corylus avellana L.) stored at $20^{\circ} \mathrm{C}$. Acta Physiol. Plant. 3, 4: 181-186.

Rahimi A., Bussler W., 1973. Dei Wirkung von Kupfermangel auf die Gewebestruktur höheren Pflanzen. Z. Pflanzenernähr. u. Bodenkunde 135: 183195.

Ruszk owska M., 1983. Fizjologiczna rola miedzi w plonowaniu owsa. V. Wplyw miedzi na pobieranie składników pokarmowych. Pam. puł. 80: 13-31.

Ruszkowska M., Eyszcz S., 1975. Aktywność oksydaz miedzio-proteidowych jako wskaźnik zaopatrzenia roślin w miedź. Pam. puł. 62: 251-263.

Ruszkowska M., Łyszcz S., Slusarczyk M., Wojcieska U., Wolska E., Zinkiewicz E., 1983. Badania nad fizjologiczną rolą miedzi w plonowaniu roślin zbożowych. Zesz. Probl. Post. Nauk Roln. 241: 167-176.

Slusarczyk M., 1976. Analiza zawartości węglowodanów. Cz. I. Prace metodyczne. Mat. sem. pt. „Wartość pokarmowa produktów roślinnych uzyskiwanych w warunkach intensywnego nawożenia". Cz. I. Wydawn. IUNG, Puławy, pp. 38-50.

Slusarczyk M., 1978. Hipotetyczny mechanizm zmian w głównych szlakach metabolicznych roślin $\mathrm{w}$ wyniku działania nawożenia azotem. Komunikat. Mater. XVI Zjazdu Pol. Tow. Bioch., Łódź, pp. 217-218.

Slus arczyk M., 1980a. Zmiany w składzie frakcji cukrowych roślin jako wskaźnik intensywności oddychania. Komunikat. Mater. XVII Zjazdu Pol. Tow. Bioch., Warszawa, p. 282.

SI us arczyk MI., 1980b. Zmiany w zawartości i składzie frakcji węglowodanowych owsa w warunkach niedoboru miedzi. Komunikat. Mater. XLV Zjazdu Pol. Tow. Bot., Lublin, 87-88.

Slusarczyk M., Marszałkowski G., Mazurek J., Molski B., 1985. Badania nad wyleganiem żyta. Cz. II. Wpływ wylegania w różnych fazach wzrostu i rozwoju żyta na zawartość i skład cukrowców w odkształconych węzłach. Biul. IHAR 156: 69-77.

Slusarczyk M., Zinkiewicz E., 1983. Rola miedzi w gromadzeniu cukrowców $\mathrm{w}$ roślinach owsa. Komunikat. Mater. XIX Zjazdu Pol. Tow. Bioch., Szczecin, p. 233.

Trevelyan W. E., Prector D. P., Harris on J. S., 1950. Detection of sugars in paper chromatograms. Nature 166, 4219: 444-445.

Weryszko E., Tomaszewski A., Ruszkowska M., 1982. Anatomical and 
morphological changes in oats (Avena sativa L.) flowers and inflorescences with copper deficiency. Proc. IX Intern. Plant Nutrition Coll., Warwick University, England, Com. Agricult. Bureaux II: 716-721.

Wojcieska U., 1982a. Fizjologiczna rola miedzi w plonowaniu owsa. I. Wpływ dawki miedzi na wielkość i strukturę plonu. Fam. puł. 77: 109-130.

Wojcieska U., 1982b. Fizjologiczna rola miedzi w plonowaniu owsa. II. Wpływ terminu stosowania miedzi na wzrost i rozwój roślin. Pam. pul. 77: 131-142.

Wojcieska U., 19̄83a. Fizjologiczna rola miedzi w plonowaniu owsa. III. Wplyw miedzi na fotosyntezę $\mathrm{i}$ aktywność reduktazy azotanowej. Pam. puł. 79: 63-83.

Wojcieska U., 1983b. Fizjologiczna rola miedzi w plonowaniu owsa. IV. Wplyw niektórych substancji wzrostowych na wzrost i rozwój owsa w warunkach niedoboru miedzi. Pam. puł. 79: 85-101.

Zinkiewicz E., Ruszkowska M., Samiec H., 1985. Rate of dark respiration of oats at various levels of copper supply. Acta Agrobot. 38: 23-32.

Zinkiewicz E., Ruszkowska M., Wojcieska U., Wolska E., 1980. The productivity of oat plants in dependence on copper nutrition. FESPP Congress II Santiago de Campostela. Abstracts of lectures and poster demonstrations: 740741.

Zinkiewicz E., Slusarczyk M., 1981. Wplyw micdzi na intensywność oddychania ciemniowego oraz na zawartość i skład węglowodanów owsa. Komunikat. Mater. XVIII Zjazdu Pol. Tow. Bioch., Wrocław, p. 286.

Wpływ miedzi na zawartość i skład cukrów w roślinach owsa

Streszczenie

Przeprowadzono badania nad zawartością i składem cukrowców w różnych organach i fazach rozwoju owsa (Avena sativa L. odm. 'Udycz Zólty') w zależności od dawek i terminu stosowania siarczanu miedzi. Material do analiz pobierano z doświadczeń wazonowych, przeprowadzonych na torfie niskim, niedoborowym pod względem miedzi. Przy niedoborze miedzi rośliny owsa zawierały mniej cukrów rozpuszczalnych, hemiceluloz i celulozy niż rośliny odpowiednio zaopatrzone w ten składnik. Zróżnicowanie $w$ zawartości poszczególnych frakcji cukrowców zależało od dawki miedzi i terminu jej stosowania, a także od organu i fazy rozwoju roślin owsa. W ziarniakach owsa, wyrosłego przy niedoborze miedzi stwierdzono zwiększone ilości cukrów pięciowęglowych (arabinozy i ksylozy) przy równoczesnym zmniejszeniu się ilości glukozy. Przedstawiono próby wyjaśnienia zmian $w$ metabolizmie cukrowców w warunkach niedoboru miedzi i udziału tego mikroelementu w procesie zawiązywania ziarna. 